\title{
Ethnobotanical notes on significant food and medicinal flora used by the indigenous Monpa and Nyishi communities of Arunachal Pradesh, India
}

\author{
Sanjib K. Das ${ }^{1}$, Tridip J. Das ${ }^{1}$, Deki Tshering ${ }^{2}$, Jambey Tsering ${ }^{4}$, Dipayan Paul ${ }^{1}$, \\ Debmalya D. Gupta ${ }^{1}$, Hage Yanka ${ }^{2}$, Momang Taram ${ }^{2}$, Sapana Bansod ${ }^{6}$, Chandraiah \\ Godugu $^{6}$, R. Ananthan ${ }^{5}$, Sanjay Jambhulkar ${ }^{3}$, Hui Tag' and Pallabi K. Hui ${ }^{1,7}$ \\ ${ }^{1}$ Department of Biotechnology, National Institute of Technology (NIT) Arunachal Pradesh, Yupia-791112, \\ Papum Pare, Arunachal Pradesh, India \\ ${ }^{2}$ Plant Systematic \& Ethnobotanical Research Laboratory, Department of Botany, Rajiv Gandhi University, \\ Rono Hills, Doimukh-791112, Arunachal Pradesh, India \\ ${ }^{3}$ Nuclear Agriculture \& Biotechnology Division, Bhabha Atomic Research Centre, Trombay, Mumbai-400085. \\ ${ }^{4}$ Orchid Research Center, Tippi, Balukpong -790114, Arunachal Pradesh, India \\ ${ }^{5}$ National Institute of Nutrition, Jamai-Osmania PO, Hyderabad-500007, Telangana, India. \\ ${ }^{6}$ Department of Regulatory Toxicology, National Institute of Pharmaceutical Education \& Research, Balanagar, \\ Hyderabad-500037, Telangana, India. \\ ${ }^{7}$ Corresponding Author; E-mail: pallabi2008rgu@gmail.com
}

[Received 30.10.2019; Revised 18.12.2019; Accepted 20.12.2019; Published 31.12.2019]

\begin{abstract}
Present paper discusses ethnobotany of the economically significant food and medicinal plants used among the Monpa and Nyishi community of West Kameng and Kamle District of Arunachal Pradesh in cross-cultural approaches. The 49 species of both cultivated and wild food and medicinal plants recorded from Monpa and Nyishi biocultural landscape are frequently harvested and used by the local communities as antioxidant food, anti-inflammatory agent and for treatment of various diseases including prevention of cancer and liver cirrhosis which has the potential to be used as nutraceuticals and capable of sustaining the rural economy and livelihood of the rural community.
\end{abstract}

Key Words: Ethnobotany, Cross-cultural, Nutraceutical Plants, Monpa and Nyishi Tribes, Arunachal Pradesh

\section{INTRODUCTION}

The state of Arunachal Pradesh is rich in floristic heritage of ethnobotanical, ecological and economic significances distributed along different altitudinal gradient ranging from tropical to snow clad alpine mountains (Tag et al. 2008). This Eastern Himalayan State of India is also blessed with 26 major tribes and 110 subtribes rich in ethnocultural knowledge systems contributing towards effective conservation and sustainable utilization of ethnobotanical resources of their traditional biocultural landscape (Tag 2007; Ranjay et al. 2007; Omem et al.2016). The forests of Arunachal Pradesh representing most of the characteristics vegetation types of India which receives heavy rainfall from both northeast and southwest monsoon that favours luxuriant growth of vegetation (Kaul \& Haridasan 1987). Given the richness of traditional biocultural knowledge prevalent among the local communities, present study aims to document ethnobotanical heritage of significant food and medicinal plants focused on 
Monpa and Nyishi tribal communities of Arunachal Pradesh. Perusal of literature has revealed few field based reports on ethnobotany of the tribal communities of Arunachal Pradesh since late 1990 focused on rapid ethnobotanical appraisal and documentation of indigenous food and medicinal botanical resources by selected workers including Dam \& Hajra (1997), Tag \& Das (2003), Gajurel et al. (2003), Tag et al. (2005), Ranjay et al. (2007), Tag et al. (2008), Jeri et al. (2011), Jambey \& Tag 2015), Rinyo et al. (2018) and Momang et al. (2018). However, there is a shortfall of cross cultural ethnobotanical database on Monpa and Nyishi communities residing in West Kameng and Kamle Districts of Arunachal Pradesh except the rapid ethnobotanical appraisal report made by Tag \& Das (2007), Jeri et al. (2011), Namsa et al. (2011), Jambey et al. (2017) and Deki et al. (2018). Thus, this article highlights ethnobotanical heritage of the two local communities (Monpa and $\mathrm{Nyishi}$ ) in cross cultural approaches focused on commercially viable food and medicinal plants capable of supporting rural livelihood system.

\section{MATERIALS AND METHODS}

\section{Study site and ethnocultural heritage}

The West Kameng district of Arunachal Pradesh with population of over 83,947 souls occupies a total geographical area of $7442 \mathrm{sq} \mathrm{km}$ which accounts for $8.86 \%$ of the total area of Arunachal Pradesh. It lies within geographical coordinate between $91^{\circ} 30^{\prime}$ to $92^{\circ} 40^{\prime}$ East Longitudes and $26^{\circ} 54^{\prime}$ to $28^{\circ} 01^{\prime}$ North Latitudes with elevation ranging from $100 \mathrm{~m}$ to 5000 $\mathrm{m}$ from the MSL (Census 2011). The forest types in the district are mixed tropical evergreen forest staring at $100-1000 \mathrm{~m}$ elevation to subtropical pine forests spreading at $1000-2300$ $\mathrm{m}$, whereas the temperate forests are between $2400-300 \mathrm{~m}$ from MSL dominated by Quercus, Rubus, Rhododendron, and Alnus. The alpine forests starts at elevation of 3200 and available up to $5000 \mathrm{~m}$ AMSL dominated by Abies, Tsuga, Juniperus, Cupressus, Rhododendron and alpine scrubs. The focussed local tribal communities of West Kameng District of Arunachal Pradesh are rich in local cultural heritage (Dhar 2005). They belong to Mongoloid racial stocks and speaks Tibeto Burman linguistic stock. Yak is their cultural animal whereas Losar is their community festival. Majority Monpas are Buddhist by religion and some of them practices Lamaism tradition of healing methods including herbal healing (Norbu 2008; Jambey \& Tag 2015).

The Nyishi dominated Kamle district of Arunachal Pradesh, with 22,256 souls, occupies a total geographical area of $850 \mathrm{sq} \mathrm{km}$ which accounts for only $1 \%$ of the total geographical area of Arunachal Pradesh. It lies within a geographical coordinate between $26^{\circ} 55^{\prime \prime}$ and $28^{\circ} 21^{\prime}$ North Latitudes and $92^{\circ} 80^{\prime}$ and $94^{\circ} 30^{\prime}$ East Longitudes (Census 2011). Physical features of the Kamle district are rich and diverse. The altitude of the district is ranging between $200 \mathrm{~m}$ and $400 \mathrm{~m}$ in the low altitude River Valleys of Kamle and Siniek and extending upto $3800 \mathrm{~m}$ from the MSL in Talley range while the highest peak is the snowclad Dicho Kato which is about $5700 \mathrm{~m}$ high. Due to the altitudinal variation, the district experiences all short of agro-climatic zones that is, tropical low land including major river valleys $(200-$ $1000 \mathrm{~m})$, subtropical zone of middle elevation hills $(1000-2000 \mathrm{~m})$, temperate $(2000-2800$ $\mathrm{m})$, subalpine and alpine zone of higher elevation mountain range $(2800-3800 \mathrm{~m})$. The Nyishi community living in the Kamle district of Arunachal Pradesh belonging to Mongoloid racial stock and speaks Tibeto Burman dialectical groups. They trace their genealogy from mythical father Abotani whom they revered as progenitor of first human being. Their traditional religion is Donyi-Polo, and they celebrate Boori Boot and Nyokum Yullo as their community festival dedicated to entire forces of nature for the blessings (Tag 2017). 
Sanjib K. Das et al. 293

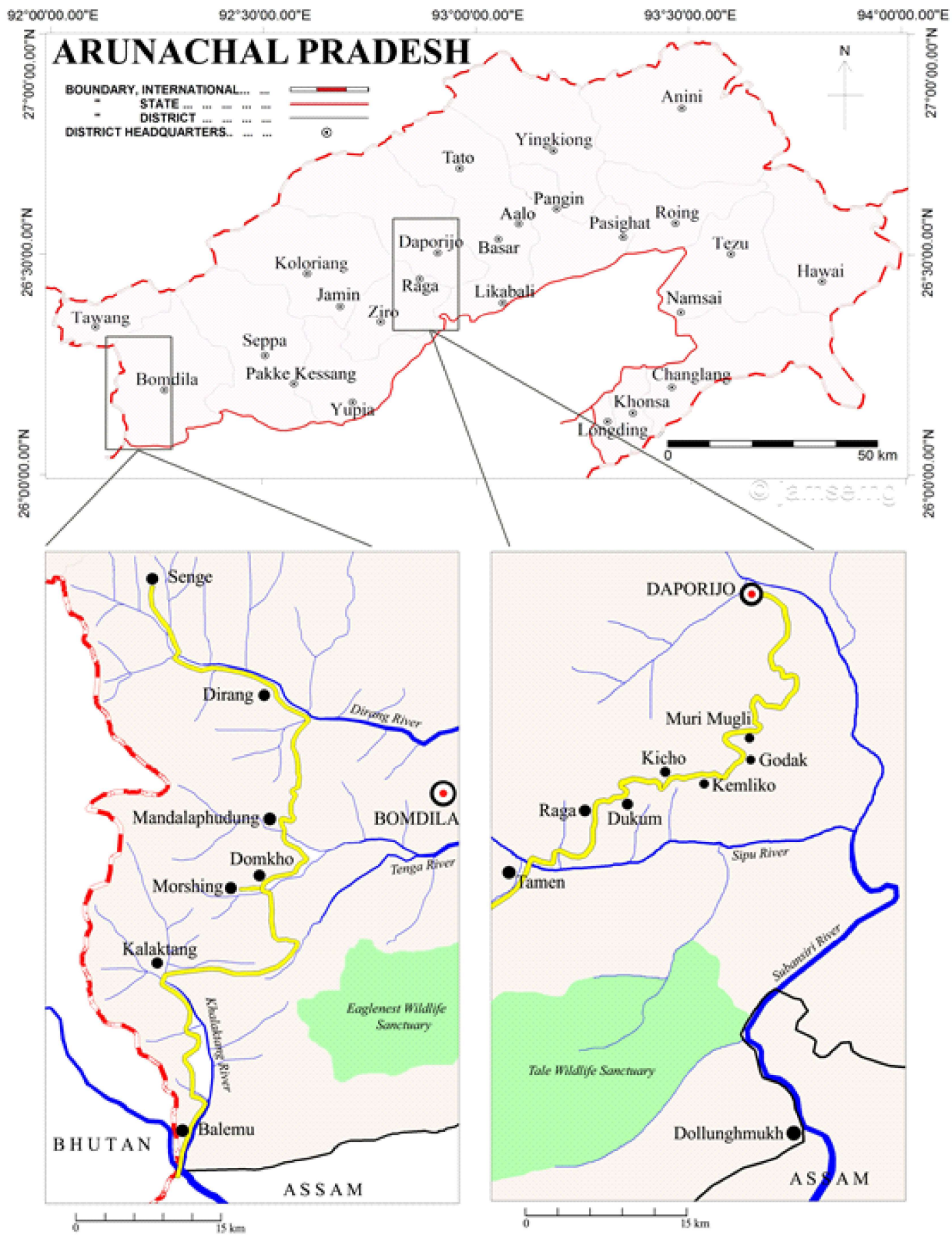

Figure 1. Map of Arunachal Pradesh showing study sites - West Kameng and Kamle Districts showing villages surveyed for gathering ethnobotanical information with GPS tracking points. 


\section{Ethnobotanical field survey}

Cross-cultural ethnobotanical field survey was conducted during the years $2017-2018$ in the Monpa and the Nyishi dominated biocultural landscape of West Kameng and Tawang District of Arunachal Pradesh following Jain \& Rao (1977) and Martin (2008) methods. A total of 60 potential informants covering 30 household from 15 villages $(7$ villages from Monpa area and 8 villages from Nyishi area) were surveyed, interviewed and ethnobotanical information on medicinal and food plants, parts harvested, distribution and their application against various ailments were recorded using structured questionnaire format. Prior Inform Consent (PIC) was taken from the potential informants before start of the work. The taxonomically authenticated herbarium specimen of all the reported species was deposited with collection and accession number in the Herbarium of Arunachal University (HAU), Department of Botany, Rajiv Gandhi University, Rono Hills, Arunachal Pradesh, India for future reference. Voucher specimens were identified with the help of standard regional floras including Flora of Assam (Kanjilal et al. 1934 - '40), The Flora of British India (Hooker 1872 - 1897), Material for the Flora of Arunachal (Hajra et al. 1996; Giri et al. 2008; Chowdhery et al. 2009), and Flora of Lower Subansiri (Pal 1993). The accepted scientific names were verified in the website www.theplantlist.org and www.worldfloraonline.org, hosted by Royal Botanic Garden, Kew, UK and Missouri Botanical Garden, St. Louis, USA, and Plants of World Online (POWO) hosted by RBG, Kew.

\section{RESULT AND DISCUSSION}

\section{Taxonomic diversity and distribution of food and medicinal plants}

Present investigation has revealed potential 49 species of traditional food and medicinal plants belonging to 40 genera and clubbed into 37 plant families (Figure 2) used by the Monpa and Nyishi communities of West Kameng and Kamle district of Arunachal Pradesh which is presented in Table 1. Herbs represent highest number of species (23 spp.), which is followed by shrubs (12 spp.), climbers ( 2 spp.) and trees (12 spp.) (Figure 3). Majority of the plants used by the two local communities are found in wild while few species are found to be cultivated in home gardens and agricultural fields. The significant ethnobotanical species reported from Monpa belt of West Kameng district are from subtropical to temperate ecosystem with elevation ranging from 1000 - 3500 m AMSL and includes Aconitum heterophyllum, Fragaria vesca, Gaultheria fragrantissima, Illicium griffithii, Lindernia neesiana, Magnolia campbelli, Meconopsis paniculata, Nasturtium officinale, Ophiocordyceps sinensis, Panax bipinnatifidus, Quercus semecarpifolia, Rheum nobile, Rhododendron arboreum, Swertia

chirayita and Vaccinium glaucoalbum. The majority of the species reported by the Nyishi tribal community of Kamle district are mostly tropical and subtropical ecosystems with elevation ranging 100 - 2000 m AMSL, which include Allium hookeri, Centella asiatica, Clerodendrum glandulosum, Dillenia indica, Diplazium esculentum, Lindernia neesiana, Litsea cubeba, Panax arunachalensis, Paris polyphylla, Phytolacca acinosa, Plantago major, Smilax glabra, Zanthoxylum armatam, and Zanthoxylum rhetsa.

Of the total 49 species reported, 6 species are exclusively harvested for food, 16 species are exclusively harvested for medicinal uses whereas 27 species reported as used as both food and medicinal purposes (Figure 5).

\section{Cross-cultural ethnobotanical uses}

Of the total 49 species, 7 species are exclusively used by the Nyishi tribal community, 24 species are exclusively used by the Monpa tribal community whereas 18 species are used by 

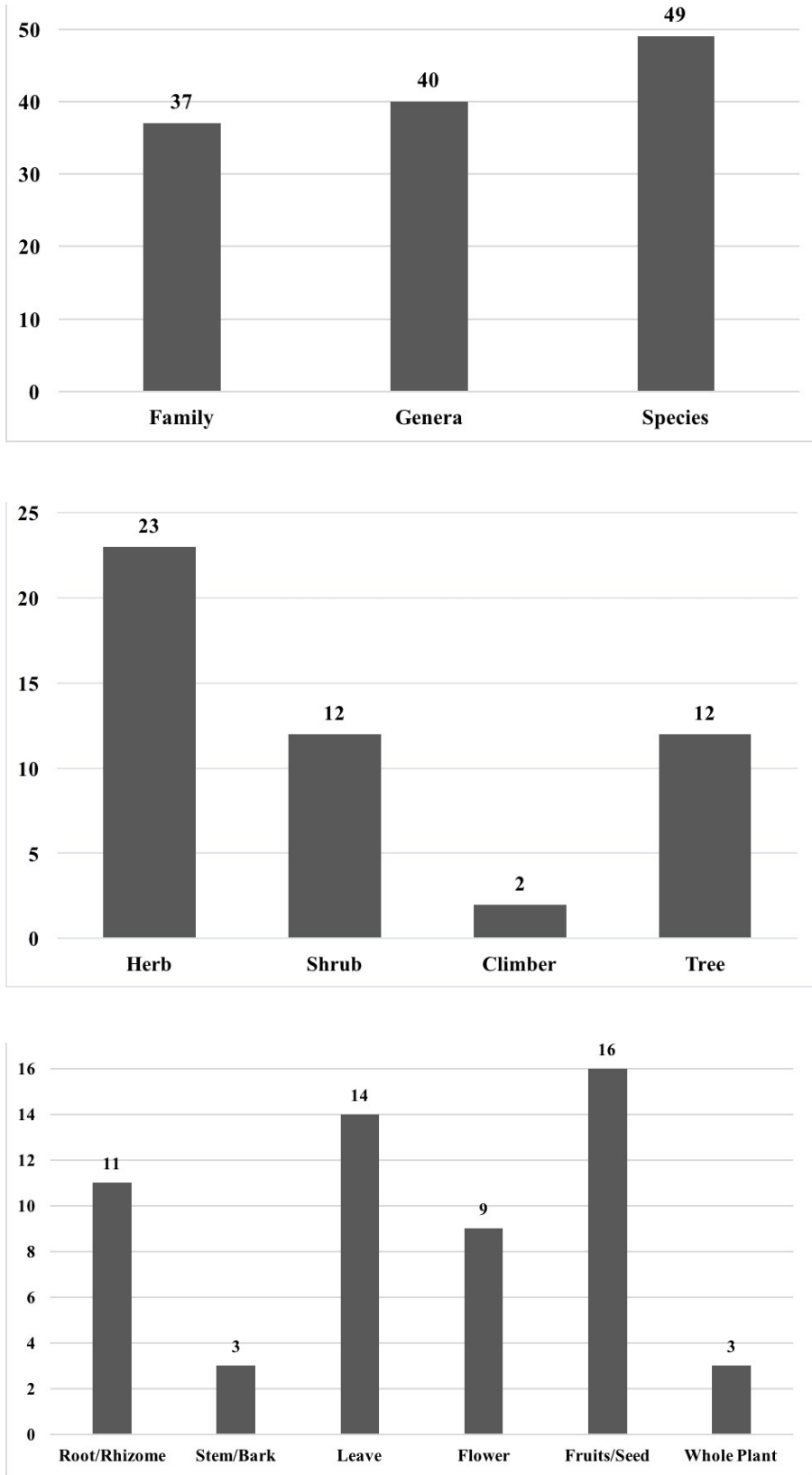

Figure 2. Taxonomic diversity of food and medicinal plant species (49 spp.) used by Monpa and Nyishi communities of West Kameng and Kamle districts of Arunachal Pradesh
Figure 3. Diversity of habit of the food and medicinal plant species (49 spp.) used by Monpa and Nyishi communities of West Kameng and Kamle districts of Arunachal Pradesh

Figure 4. Statistics of plant parts harvested as food and medicinal agents (49 spp.; 56 plant parts) used by Monpa and Nyishi communities of West Kameng and Kamle districts of Arunachal Pradesh

both the tribal community, namely, Monpa and Nyishi as food and medicinal purposes (Figure 6). The 18 species which are used by both the communities are mostly reported from tropical and subtropical climatic regimes. These consensus species are commercially viable and frequently harvested species having high food and medicinal values found in the traditional biocultural landscape of Monpa and Nyishi communities. Some of the significant species reported to be commonly used by both the community are Aconitum heterophyllum, Aconogonum molle, Allium hookeri, Colocasia esculenta, Diplazium esculentum, Houttuynia cordata, Litsea cubeba, Paris polyphylla, Rubia manjith and Zanthoxylum rhetsa. These species are capable of enhancing rural food security, employment opportunities and livelihood security. 

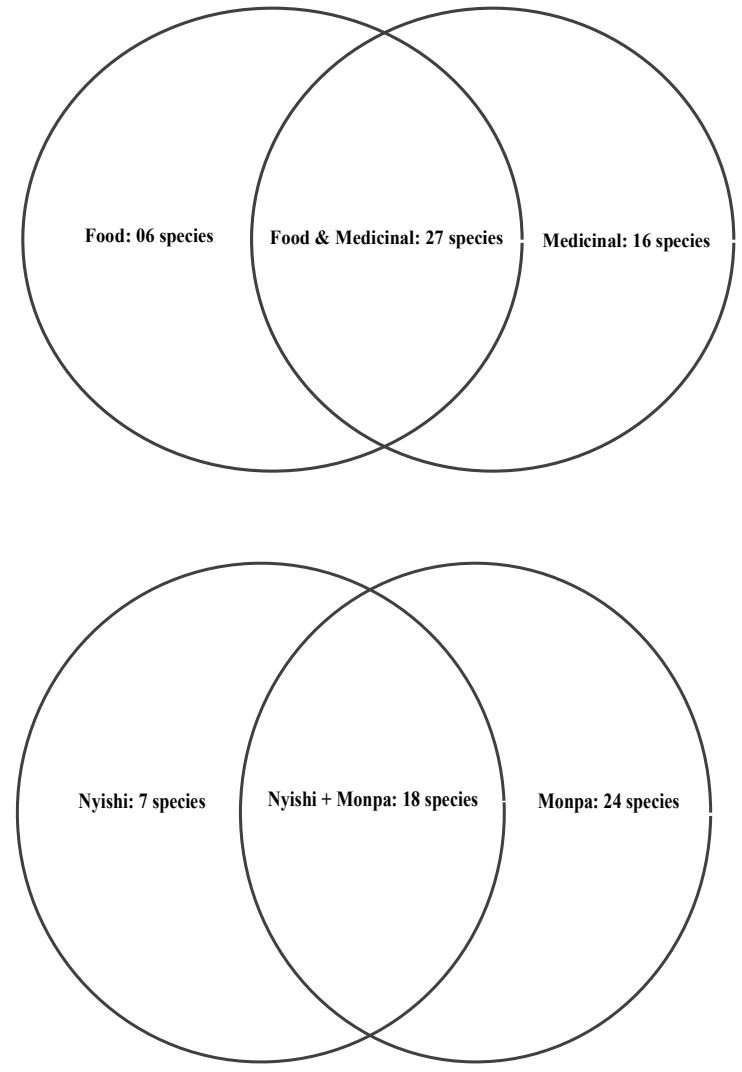

Figure 5. Diversity of plant species (49 spp.) used as food, medicinal, both food and medicinal agents by the Monpa and Nyishi tribal community of West Kameng and Kamle district of Arunachal Pradesh.

Figure 6. Cross-cultural uses of food and medicinal plant species (49 spp.) used by the Monpa and Nyishi tribal community of West Kameng and Kamle district of Arunachal Pradesh.

\section{Diversity of plant parts harvested and ailment treated}

Of the total 56 plant parts harvested from 49 species of food and medicinal plants for food and medicinal applications, fruits and seeds represent highest number (16 spp.), leaves (14 spp.), root or rhizome and flowers represented by 11 species each whereas stem or bark and whole plant represent 3 species each which is presented in Figure 4 . The 56 plant parts harvested are either consumed as food and used for treatment of 27 diseases and ailments ranging from sexual debility to liver cirrhosis, cancer, high blood pressure, skin inflammation, chest and lung inflammation, cardio tonic to viral fever, cough, dysentery, and diarrhea. The healers of the Nyishi community of Abotani descendant residing in Kamle district is either known as Nyub or Nwn Pon Nwn Bo who is well versed in Donyi-Polo healing tradition of the community. The Nwn Pon Nwn Bo is frequently invited by the villagers to heal the ailments of the patient using different parts of the medicinal plants with invocation of spiritual hymns in certain case for effective healing. In the Monpa localities of West Kameng district, local villagers are dependent on local traditional healing practices called Bon medicine. The knowledgeable local healers of the Monpa community is called Bonpo who are professional in healing ailments of the villagers using different types of medicinal herbs and animal products. Apart from local Bon medicine and allopathic medicine, they (Monpa) also take the support of the service of Swa-Rigpa, the Tibetan Buddhist medical system for alternative healthcare.

\section{Frequently harvested food and nutraceutical plants}

The commercially viable food and nutraceutical species frequently harvested and sold in the market are Allium hookeri, Bergenia ciliata, Centella asiatica, Clerodendrum 


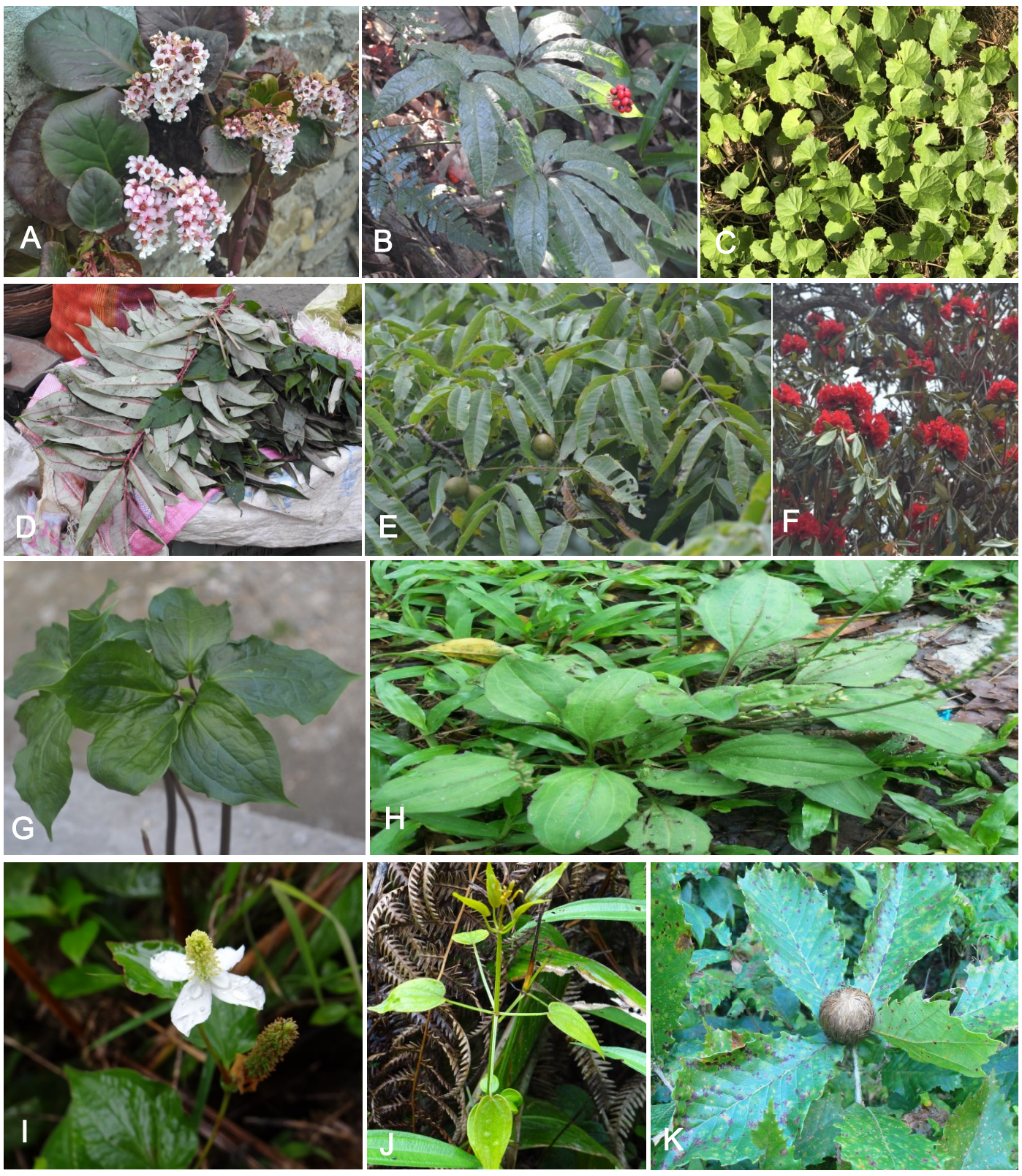

PLATE - I. Some ethnomedicinal plants used by Monpa and Nyishi tribes of Arunachal Pradesh: A. Berginia ciliata; B. Panax arunachalensis; C. Centella asiatica; D. Zanthoxylum rhetsa; E. Juglans regia; F. Rhododendrom arboreum; G. Paris polyphylla; H. Plantago major; I. Houttuynia cordata; J. Rubia manjith; K. Quercus griffithii

glandulosum, Colocasia esculenta, Dillenia indica, Diplazium esculentum, Houttuynia cordata, Litsea cubeba, Paris polyphylla, Zanthoxylum armatum, and Zanthoxylum rhetsa. These plants are frequently harvested and popularly consumed as food, medicinal, spice and condiments in the Monpa and Nyishi belt of West Kameng and Kamle District of Arunachal Pradesh which is potential to ensure rural food, nutritional and nutraceutical security. 
Table 1. Checklist of significant food and medicinal plants used by the Monpa and Nyishi tribes of Arunachal Pradesh

\begin{tabular}{|c|c|c|c|c|}
\hline Name & $\begin{array}{l}\text { Local Name } \\
\text { (Monpa/ } \\
\text { Nyishi) }\end{array}$ & Habit & $\begin{array}{l}\text { Part } \\
\text { harvests }\end{array}$ & $\begin{array}{l}\text { Traditional Uses/ } \\
\text { Ailment cured }\end{array}$ \\
\hline $\begin{array}{l}\text { Aconitum heterophyllum Wall. ex } \\
\text { Royle [Ranunculaceae]; } \\
\text { SK/HT/HAU/1520/2017 }\end{array}$ & $\begin{array}{l}\text { Gonga } \\
\text { Karpu }(\mathrm{M}) \\
\text { Omli }(\mathrm{N})\end{array}$ & Herb & Root & $\begin{array}{l}\text { Powder of dried roots are } \\
\text { used as arrow poison. Small } \\
\text { quantity of powder is used } \\
\text { for treatment of malarial } \\
\text { fever. }\end{array}$ \\
\hline $\begin{array}{l}\text { Acorus calamus L. [Acoraceae]; } \\
\text { SK/HT/HAU/1575/2018 }\end{array}$ & Shueta (M) & Herb & $\begin{array}{l}\text { Rhizo- } \\
\text { me }\end{array}$ & $\begin{array}{l}\text { The paste of rhizome is used } \\
\text { for curing skin infection such } \\
\text { as scabies. }\end{array}$ \\
\hline $\begin{array}{l}\text { Allium hookeri Thwaites } \\
\text { [Amaryllidaceae]; } \\
\text { HT/SK/HAU/1540/2017 }\end{array}$ & $\begin{array}{l}\text { Tschong }(\mathrm{M}) \\
\text { Mud Talap } \\
(\mathrm{N})\end{array}$ & Herb & $\begin{array}{l}\text { Bulb, } \\
\text { Leaf }\end{array}$ & $\begin{array}{l}\text { Bulb and leaves are used } \\
\text { eaten raw as salad. Leaves } \\
\text { are used for curing debility, } \\
\text { fatigue and insomnia. }\end{array}$ \\
\hline $\begin{array}{l}\text { Berberis aristata DC } \\
\text { [Berberidaceae]; } \\
\text { HT/SK/HAU/1556/2017 }\end{array}$ & $\begin{array}{l}\text { Kanchan } \\
\text { (M) }\end{array}$ & Shrub & $\begin{array}{l}\text { Root, } \\
\text { Flower, } \\
\text { Fruit }\end{array}$ & $\begin{array}{l}\text { Tender shoot, flowers and } \\
\text { fruits are eaten raw }\end{array}$ \\
\hline $\begin{array}{l}\text { Berberis asiatica } \text { Roxb. ex DC } \\
\text { [Berberidaceae]; } \\
\text { HT/SK/HAU/1534/2018 }\end{array}$ & $\begin{array}{l}\text { Kanchan } \\
\text { (M) }\end{array}$ & Shrub & $\begin{array}{l}\text { Leaf, } \\
\text { Flower, } \\
\text { berry }\end{array}$ & $\begin{array}{l}\text { Leaf, flower and berry are } \\
\text { edible. Water decoction are } \\
\text { used for curing inflammation } \\
\text { and stomache. }\end{array}$ \\
\hline $\begin{array}{l}\text { Bergenia ciliata (Haw.) Sternb. } \\
\text { [Saxifragaceae]; } \\
\text { HT/SK/HAU/1596/2018 }\end{array}$ & $\begin{array}{l}\text { Bra-mento } \\
\text { (M) }\end{array}$ & Herb & $\begin{array}{l}\text { Roots, } \\
\text { Tuber }\end{array}$ & $\begin{array}{l}\text { Infusion of roots and } \\
\text { rhizome is used for treating } \\
\text { inflammation of hand, legs, } \\
\text { boils and sores. Decoction of } \\
\text { rhizome is also used as } \\
\text { aphrodisiac agent. }\end{array}$ \\
\hline $\begin{array}{l}\text { Centella asiatica (L.) Urb. } \\
\text { [Apiaceae]; } \\
\text { HT/DT/HAU/1526/2018 }\end{array}$ & $\begin{array}{l}\text { Buri Kiik } \\
\text { (N) }\end{array}$ & Herb & $\begin{array}{l}\text { Leaf, } \\
\text { stem }\end{array}$ & $\begin{array}{l}\text { Raw or powdered leaves are } \\
\text { consumed as salad. The } \\
\text { powdered leaves are used } \\
\text { against lung infection, tissue } \\
\text { inflammation, liver cirrhosis, } \\
\text { stomach ulcer and diarrheoa } \\
\text { and brain stimulant. }\end{array}$ \\
\hline $\begin{array}{l}\text { Clerodendrum glandulosum Lindl. } \\
\text { [Lamiaceae]; } \\
\text { HT/SK/HAU/1533/2018 }\end{array}$ & $\begin{array}{l}\text { Khangjela- } \\
\text { Shing }(\mathrm{M}) \text {, } \\
\text { Poto oh }(\mathrm{N})\end{array}$ & Shrub & Leaf & $\begin{array}{l}\text { Young leaves are cooked and } \\
\text { consumed as vegetable. It is } \\
\text { also consumed to cure high } \\
\text { blood pressure, liver } \\
\text { complaint and insomnia. }\end{array}$ \\
\hline $\begin{array}{l}\text { Colocasia esculenta (L.) Schott } \\
\text { [Araceae]; HT/SK/HAU/1548/2018 }\end{array}$ & $\begin{array}{l}\operatorname{Ngaglin}(\mathrm{M}) \\
\text { Enge }(\mathrm{N})\end{array}$ & Herb & Corm & $\begin{array}{l}\text { The corm (tuber) is cooked } \\
\text { and eaten as food supplement } \\
\text { and help to cure constipation. }\end{array}$ \\
\hline $\begin{array}{l}\text { Cynoglossum lanceolatum } \text { Forssk. } \\
\text { [Boraginaceae]; } \\
\text { HT/SK/HAU/1529/2018 }\end{array}$ & $\begin{array}{l}\text { Nat } \\
\text { Sancharik } \\
(\mathrm{M}), \text { Sibin } \\
\text { Taglam }(\mathrm{N})\end{array}$ & Herb & $\begin{array}{l}\text { Leaf, } \\
\text { root }\end{array}$ & $\begin{array}{l}\text { Root-paste cures } \\
\text { inflammation, cuts \& } \\
\text { wounds, fractured bone, boil } \\
\text { and sores. Leaves are cooked } \\
\text { and eaten raw. Roots are } \\
\text { chewed as mouth freshner. }\end{array}$ \\
\hline $\begin{array}{l}\text { Daphne papyracea Wall. ex G. } \\
\text { Don [Thymelaeaceae]; } \\
\text { HT/SK/HAU/1518/2018 }\end{array}$ & $\begin{array}{l}\text { Shugu-sheng } \\
\text { (M) }\end{array}$ & Shrub & Bark & $\begin{array}{l}\text { Bark fiber is used for making } \\
\text { local handmade paper among } \\
\text { by Monpas. }\end{array}$ \\
\hline
\end{tabular}




\begin{tabular}{|c|c|c|c|c|}
\hline Name & $\begin{array}{l}\text { Local Name } \\
\text { (Monpa/ } \\
\text { Nyishi) }\end{array}$ & Habit & $\begin{array}{l}\text { Part } \\
\text { harvests }\end{array}$ & $\begin{array}{l}\text { Traditional Uses/ } \\
\text { Ailment cured }\end{array}$ \\
\hline $\begin{array}{l}\text { Dillenia indica } \mathrm{L} . \text { [Dilleniaceae]; } \\
\mathrm{HT} / \mathrm{SK} / \mathrm{HAU} / 1512 / 2018\end{array}$ & Soot Aas $(\mathrm{N})$ & Tree & Fruit & $\begin{array}{l}\text { Pulp of fruit is cooked is } \\
\text { edible as vegetable and } \\
\text { chutney. It is also taken to } \\
\text { cure liver inflammation and } \\
\text { cancer. }\end{array}$ \\
\hline $\begin{array}{l}\text { Diplazium esculentum (Retz.) Sw. } \\
\text { [Athyriaceae]; } \\
\text { HT/DT/HAU/1516/2017 }\end{array}$ & $\begin{array}{l}\text { Dangsum } \\
\text { (M) } \\
\text { Tak Peya } \\
\text { (N) }\end{array}$ & Herb & $\begin{array}{l}\text { Young } \\
\text { frond }\end{array}$ & $\begin{array}{l}\text { The young fronds are cooked } \\
\text { and consumed as vegetable. } \\
\text { The fresh juice of young } \\
\text { frond is also used for healing } \\
\text { freshly cut wound. } \\
\text { Decoction are used to cure } \\
\text { insomnia, liver } \\
\text { inflammation. }\end{array}$ \\
\hline $\begin{array}{l}\text { Fragaria vesca L. [Rosaceae]; } \\
\text { HT/DT/HAU/1558/2018 }\end{array}$ & $\begin{array}{l}\text { Sa-merp }(\mathrm{M}) \\
\text { Suji hench } \\
\text { (N) }\end{array}$ & Herb & Fruit & $\begin{array}{l}\text { Beery are sweet and edible. } \\
\text { It is also consumed to clear } \\
\text { chest inflammation. }\end{array}$ \\
\hline $\begin{array}{l}\text { Gaultheria fragrantissima Wall. } \\
\text { [Ericaceae]; } \\
\text { HT/DT/HAU/1522/2018 }\end{array}$ & $\begin{array}{l}\text { Shegshing } \\
\text { mrep }(\mathrm{M})\end{array}$ & Shrub & Fruit & $\begin{array}{l}\text { Fruits are sweet eaten raw } \\
\text { and also used for curing } \\
\text { hookworm. }\end{array}$ \\
\hline $\begin{array}{l}\text { Houttuynia cordata Thunb. } \\
\text { [Saururaceae]; } \\
\text { HT/SK/HAU/1524/2018 }\end{array}$ & $\begin{array}{l}\text { Mreptang } \\
(\mathrm{M}) \\
\text { Hiya oh }(\mathrm{N})\end{array}$ & Herb & $\begin{array}{l}\text { Whole } \\
\text { plant }\end{array}$ & $\begin{array}{l}\text { Roots, stem and leaves are } \\
\text { used for curing typhoid } \\
\text { fever, and insomnia, boil and } \\
\text { sores, lung and liver } \\
\text { inflammation. Paste of } \\
\text { aromatic whole plant is also } \\
\text { used as salad and appetizer. }\end{array}$ \\
\hline $\begin{array}{l}\text { Illicium griffithii Hook.f. \& } \\
\text { Thomson [Schisandraceae]; } \\
\text { HT/DT/1533/2018 }\end{array}$ & Lisi (M) & Tree & $\begin{array}{l}\text { Flower, } \\
\text { fruit }\end{array}$ & $\begin{array}{l}\text { Flower and fruits are used as } \\
\text { spice and condiment. Dried } \\
\text { fruits and bark are used for } \\
\text { curing stomach and asthma. }\end{array}$ \\
\hline $\begin{array}{l}\text { Juglans regia L. [Juglandaceae]; } \\
\mathrm{HT} / \mathrm{JT} / \mathrm{HAU} / 1519 / 2018\end{array}$ & Kae (M) & Tree & Fruit & $\begin{array}{l}\text { Nut of the fruit are rich in fat } \\
\text { and edible, sold in the } \\
\text { market in high price. }\end{array}$ \\
\hline $\begin{array}{l}\text { Lindera neesiana (Wall. ex Nees) } \\
\text { Kurz [Lauraceae]; } \\
\text { HT/DT/1523/2018 }\end{array}$ & $\begin{array}{l}\text { Langkarma- } \\
\text { sing }(\mathrm{M}) \text {, } \\
\text { Kusuk Siin } \\
(\mathrm{N})\end{array}$ & Tree & $\begin{array}{l}\text { Fruit, } \\
\text { seed }\end{array}$ & $\begin{array}{l}\text { Seeds used against diarrhea, } \\
\text { scabies, anthelmintic; fruits } \\
\text { used as condiments. }\end{array}$ \\
\hline $\begin{array}{l}\text { Litsea cubeba (Lour.) Pers. } \\
\text { [Lauraceae ]; HT/DT/1536/2018 }\end{array}$ & $\begin{array}{l}\text { Nge, } \\
\text { Nyangshing } \\
\text { (M), Siin tir } \\
\text { (N) }\end{array}$ & Tree & Fruit & $\begin{array}{l}\text { Fruit is used to cure viral } \\
\text { fever, stomach ache } \\
\text { insomnia. Raw fruits are } \\
\text { consumed as spice and } \\
\text { condiment along with rice. }\end{array}$ \\
\hline $\begin{array}{l}\text { Magnolia campbellii Hook.f. \& } \\
\text { Thomson [Magnoliaceae]; } \\
\text { HT/HAU/1539/2017 }\end{array}$ & & Shrub & Flower & $\begin{array}{l}\text { Flower is boiled and } \\
\text { consumed as food } \\
\text { supplement. }\end{array}$ \\
\hline $\begin{array}{l}\text { Meconopsis paniculata (D.Don) } \\
\text { Prain [Papaveraceae]; } \\
\text { HT/SK/HAU/1553/2017 }\end{array}$ & Upal (M) & Herb & $\begin{array}{l}\text { Leaves, } \\
\text { flower }\end{array}$ & $\begin{array}{l}\text { Tender shoot, leaves and } \\
\text { flower are edible as } \\
\text { vegetable. }\end{array}$ \\
\hline $\begin{array}{l}\text { Nasturtium officinale } \mathrm{R} . \mathrm{Br} \text {. } \\
\text { [Brassicaceae]; } \\
\text { HT/SK/HAU/1547/2017 }\end{array}$ & $\begin{array}{l}\text { Silang Sag } \\
\text { (M) }\end{array}$ & Herb & $\begin{array}{l}\text { Shoot } \\
\text { part }\end{array}$ & $\begin{array}{l}\text { Tender shoots are edible } \\
\text { after cooking. It is also } \\
\text { cooked to feed swine. }\end{array}$ \\
\hline
\end{tabular}




\begin{tabular}{|c|c|c|c|c|}
\hline Name & $\begin{array}{l}\text { Local Name } \\
\text { (Monpa/ } \\
\text { Nyishi) } \\
\end{array}$ & Habit & $\begin{array}{l}\text { Part } \\
\text { harvests }\end{array}$ & $\begin{array}{l}\text { Traditional Uses/ } \\
\text { Ailment cured }\end{array}$ \\
\hline $\begin{array}{l}\text { Ophiocordyceps sinensis (Berk.) } \\
\text { G.H Sung, J.M Sung, Hywel-Jones } \\
\text { \& Spatafora } \\
\text { [Ophiocordycipitaceae]; } \\
\text { HT/HAU/1541/2018 }\end{array}$ & $\begin{array}{l}\text { Yrar-tsa- } \\
\text { gunbu (M) }\end{array}$ & Herb & $\begin{array}{l}\text { Whole } \\
\text { plant }\end{array}$ & $\begin{array}{l}\text { The powdered whole plant } \\
\text { part is eaten raw as } \\
\text { cardiotonic and reproductive } \\
\text { tonic. It is also used for } \\
\text { curing cough, respiratory } \\
\text { trouble, skin inflammation, } \\
\text { analgesic and chronic fever. }\end{array}$ \\
\hline $\begin{array}{l}\text { Panax arunachalensis M.Taram, } \\
\text { A.P. Das \& H.Tag } \\
\text { [Araliaceae];MT/HT/1505/2018 }\end{array}$ & $\begin{array}{l}\text { Mokam } \\
\text { Pigri }(\mathrm{N})\end{array}$ & Herb & $\begin{array}{l}\text { Rhizo- } \\
\text { me }\end{array}$ & $\begin{array}{l}\text { Decoction of dried or raw } \\
\text { tuber is taken orally to cure } \\
\text { sexual debility, boost } \\
\text { immunity, vigor and vitality. } \\
\text { Rhizome power is also used } \\
\text { for curing chest liver } \\
\text { inflammation, joint pain, } \\
\text { stomach flatulence. }\end{array}$ \\
\hline $\begin{array}{l}\text { Panax bipinnatifidus Seem. } \\
\text { [Araliaceae]; } \\
\text { HT/SK/HAU/1542/2017 }\end{array}$ & $\begin{array}{l}\text { Mud Pigri } \\
\text { (N) }\end{array}$ & Herb & $\begin{array}{l}\text { Tuber, } \\
\text { fruit }\end{array}$ & $\begin{array}{l}\text { Tubers used in all medicinal } \\
\text { formulation to use for lung, } \\
\text { liver inflammation, skin } \\
\text { ulcer, stomach ulcer. Tuber } \\
\text { decoction consumed as } \\
\text { aphrodisiac and health tonic. } \\
\text { Mature fruits eaten raw. }\end{array}$ \\
\hline $\begin{array}{l}\text { Panax bipinnatifidus var. angustif } \\
\text { olius (Burkill) J.Wen [Araliaceae]; } \\
\text { HT/SK/HAU/1597/2018 }\end{array}$ & $\begin{array}{l}\text { Mud Siw } \\
\text { Pigri (N) }\end{array}$ & Herb & $\begin{array}{l}\text { Rhizo- } \\
\text { me/tuber }\end{array}$ & $\begin{array}{l}\text { Rhizome are harvested after } \\
5 \text { year and used in for } \\
\text { formulation of food and anti- } \\
\text { inflammatory, boil and sores, } \\
\text { ulcer herbal medicine. } \\
\text { Decoction of tuber consumed } \\
\text { as health tonic. Ripen fruits } \\
\text { eaten raw. }\end{array}$ \\
\hline $\begin{array}{l}\text { Paris polyphylla } \text { Sm.[ } \\
\text { Melanthiaceae]; } \\
\text { HT/HAU/1557/2017 }\end{array}$ & $\begin{array}{l}\text { Mungong } \\
\text { (M) } \\
\text { Mutum Enge } \\
\text { (N) }\end{array}$ & Herb & Tuber & $\begin{array}{l}\text { Dried tuber is used for } \\
\text { treatment of debility and boil } \\
\text { and sores, skin inflammation, } \\
\text { chest inflammation. The } \\
\text { leaves and fruits are edible. }\end{array}$ \\
\hline $\begin{array}{l}\text { Phytolacca acinosa } \text { Roxb. } \\
\text { [Phytolaccaceae]; } \\
\text { HT/SK/HAU/1559/2017 }\end{array}$ & $\begin{array}{l}\text { Holap oh } \\
(\mathrm{N})\end{array}$ & Herb & Leaf & $\begin{array}{l}\text { Tender shoot is cooked and } \\
\text { consumed as vegetable, also } \\
\text { consume to cure constipation } \\
\text { and indigestion. }\end{array}$ \\
\hline $\begin{array}{l}\text { Piper pedicellatum C. DC. } \\
\text { [Piperaceae]; } \\
\text { HY/HT/HAU/1646/2019 }\end{array}$ & Riir $O h(\mathrm{~N})$ & Herb & Leaf & $\begin{array}{l}\text { Leaf are boiled and } \\
\text { consumed as vegetable; also } \\
\text { consume to regulate high } \\
\text { blood pressure and insomnia. }\end{array}$ \\
\hline $\begin{array}{l}\text { Plantago major L.[ } \\
\text { Plantaginaceae]; } \\
\text { HT/DT/HAU/1561/2017 }\end{array}$ & $\begin{array}{l}\text { Tsa Shing } \\
\text { (M) } \\
\text { Sob Nyuru } \\
\text { (N) }\end{array}$ & Herb & $\begin{array}{l}\text { Stem, } \\
\text { leaf }\end{array}$ & $\begin{array}{l}\text { The leaves are used for } \\
\text { preventing bleeding in } \\
\text { freshly cut wound. It is also } \\
\text { consumed as vegetable. }\end{array}$ \\
\hline $\begin{array}{l}\text { Polygonum molle D. Don } \\
\text { [Polygonaceae]; } \\
\text { SK/HT/HAU/1590/2017 }\end{array}$ & $\begin{array}{l}\text { Chomcha } \\
(\mathrm{M}) \\
\text { Buku (N) }\end{array}$ & Shrub & $\begin{array}{l}\text { Root, } \\
\text { young } \\
\text { shoot }\end{array}$ & $\begin{array}{l}\text { Young shoots are taken as } \\
\text { vegetable. Young stem is } \\
\text { chewed to quench thirst and } \\
\text { enhance appetite. }\end{array}$ \\
\hline
\end{tabular}




\begin{tabular}{|c|c|c|c|c|}
\hline Name & $\begin{array}{l}\text { Local Name } \\
\text { (Monpa/ } \\
\text { Nyishi) } \\
\end{array}$ & Habit & $\begin{array}{l}\text { Part } \\
\text { harvests }\end{array}$ & $\begin{array}{l}\text { Traditional Uses/ } \\
\text { Ailment cured }\end{array}$ \\
\hline $\begin{array}{l}\text { Quercus griffithii Hook.f \& } \\
\text { Thomson ex Miq. [Fagaceae]; } \\
\text { HT/HAU/1563/2017 }\end{array}$ & $\begin{array}{l}\text { Pa-sheng } \\
(\mathrm{M}) \\
\text { Sikek }(\mathrm{N})\end{array}$ & Tree & Fruits & $\begin{array}{l}\text { Nut are crushed into floor } \\
\text { and eaten as source of } \\
\text { reserved fat. Also taken as } \\
\text { famine food when food stock } \\
\text { run out. }\end{array}$ \\
\hline $\begin{array}{l}\text { Quercus semecarpifolia } \mathrm{Sm} . \\
\text { [Fagaceae];HT/HAU/1568/2018 }\end{array}$ & $\begin{array}{l}\text { Khatchang } \\
(\mathrm{M}) \\
\text { Sikek }(\mathrm{N})\end{array}$ & Tree & $\begin{array}{l}\text { Fruit/ } \\
\text { timber }\end{array}$ & $\begin{array}{l}\text { Nut is crushed into floor, } \\
\text { mixed with rice and maize, } \\
\text { eaten as nutritious foodstuff. }\end{array}$ \\
\hline $\begin{array}{l}\text { Rheum nobile Hook.f \& Thomson } \\
\text { [Polygonaceae ]; } \\
\text { HT/HAU/1566/2018 }\end{array}$ & $\begin{array}{l}\text { Chuma- } \\
\text { tsema- } \\
\text { tsumkar }(\mathrm{M})\end{array}$ & Herb & Root & $\begin{array}{l}\text { Decoction of roots are orally } \\
\text { consumed to cure } \\
\text { reproductive problem, } \\
\text { jaundice, cough, tonsillitis } \\
\text { and tuberculosis and } \\
\text { common cold. }\end{array}$ \\
\hline $\begin{array}{l}\text { Rhododendron anthopogon D. } \\
\text { Don [Ericaceae]; } \\
\text { HT/HAU/1569/2018 }\end{array}$ & Bolu (M) & Shrub & $\begin{array}{l}\text { Leaf, } \\
\text { Flower }\end{array}$ & $\begin{array}{l}\text { Leaves infusion are used to } \\
\text { enhance appetite and } \\
\text { stimulant, and leaf juice is } \\
\text { used for curing skin } \\
\text { infection. Flowers are used } \\
\text { against reproductive diseases } \\
\text { and correction of vocal cord. }\end{array}$ \\
\hline $\begin{array}{l}\text { Rhododendron arboreum } \mathrm{Sm} . \\
\text { [Ericaceae]; } \\
\text { HT/SK/HAU/1575/2017 }\end{array}$ & $\begin{array}{l}\text { Woodung- } \\
\text { sheng, Somu } \\
(\mathrm{M})\end{array}$ & Tree & $\begin{array}{l}\text { Leaf, } \\
\text { Flower }\end{array}$ & $\begin{array}{l}\text { Decoction of flower is taken } \\
\text { to cure dysentery, headache, } \\
\text { diarrhea. Flowers are eaten } \\
\text { raw or cooked. Squash made } \\
\text { of corolla extracts rich in } \\
\text { carbohydrates and vitamins. } \\
\text { Tender leaves are used as } \\
\text { vegetable. }\end{array}$ \\
\hline $\begin{array}{l}\text { Rhododendron fulgens Hook.f. } \\
\text { [Ericaceae]; } \\
\text { HT/SK/HAU/1578/2018 }\end{array}$ & $\begin{array}{l}\text { Tame- } \\
\text { mento- } \\
\text { marpu }(\mathrm{M})\end{array}$ & Shrub & Flower & $\begin{array}{l}\text { Decoction of flower is taken } \\
\text { orally to prevent nose } \\
\text { bleeding and blood } \\
\text { dysentery. }\end{array}$ \\
\hline $\begin{array}{l}\text { Rhododendron hodgsonii Hook.f. } \\
\text { [Ericaceae]; } \\
\text { HT/SK/HAU/1574/2018 }\end{array}$ & $\operatorname{Laah}(\mathrm{M})$ & Shrub & Leaf & $\begin{array}{l}\text { Young leaves are eaten raw } \\
\text { to induce emetic tendency to } \\
\text { remove food poisoning } \\
\text { inside stomach. }\end{array}$ \\
\hline $\begin{array}{l}\text { Rubia manjith Roxb. ex Fleming } \\
\text { [Rubiaceae]; } \\
\text { HT/DT/HAU/1575/2017 }\end{array}$ & $\begin{array}{l}\text { Tsot-sheng } \\
(\mathrm{M}) \\
\text { Tamen }(\mathrm{N})\end{array}$ & $\begin{array}{l}\text { Clim- } \\
\text { ber }\end{array}$ & Root & $\begin{array}{l}\text { Root paste is used for curing } \\
\text { chest pain, ulcer, skin itching } \\
\text { and skin inflammation. }\end{array}$ \\
\hline $\begin{array}{l}\text { Smilax glabra Roxb. } \\
\text { [Smilacaceae]; } \\
\text { HT/HAU/1584/2017 }\end{array}$ & $\operatorname{Pipik}(\mathrm{N})$ & $\begin{array}{l}\text { Clim- } \\
\text { ber }\end{array}$ & $\begin{array}{l}\text { Root, } \\
\text { fruit }\end{array}$ & $\begin{array}{l}\text { The decoction of roots and } \\
\text { fruits are used for curing } \\
\text { liver cirrhosis, lung problem, } \\
\text { chronic ulcer and chest and } \\
\text { joint inflammation. }\end{array}$ \\
\hline $\begin{array}{l}\text { Solanum betaceum Cav. } \\
\text { [Solanaceae]; } \\
\text { HT/HAU/1580/2018 }\end{array}$ & $\begin{array}{l}\text { Pahari } \\
\text { Tomato (M) }\end{array}$ & Shrub & Fruit & $\begin{array}{l}\text { Ripen fruit is cooked and } \\
\text { consumed as food along with } \\
\text { rice. }\end{array}$ \\
\hline $\begin{array}{l}\text { Swertia chirayita (Roxb.) Buch.- } \\
\text { Ham. ex C.B.Clarke } \\
\text { [Gentianaceae]; } \\
\text { HT/SK/HAU/1587/2017 }\end{array}$ & Tiktah (M) & Herbs & $\begin{array}{l}\text { Whole } \\
\text { plant }\end{array}$ & $\begin{array}{l}\text { Decoction of root is used for } \\
\text { curing fever, malarial fever, } \\
\text { cough and high blood } \\
\text { pressure. }\end{array}$ \\
\hline
\end{tabular}




\begin{tabular}{|l|l|l|l|l|}
\hline \multicolumn{1}{|c|}{ Name } & $\begin{array}{l}\text { Local Name } \\
\text { (Monpa/ } \\
\text { Nyishi) }\end{array}$ & Habit & $\begin{array}{l}\text { Part } \\
\text { harvests }\end{array}$ & $\begin{array}{l}\text { Traditional Uses/ } \\
\text { Ailment cured }\end{array}$ \\
\hline $\begin{array}{l}\text { Taxus wallichiana Zucc. } \\
\text { [Taxaceae]; } \\
\text { HT/SK/HAU/1588/2017 }\end{array}$ & $\begin{array}{l}\text { Tae-sheng } \\
(\mathrm{M})\end{array}$ & Tree & Flower & $\begin{array}{l}\text { Flower are edible. Leave are } \\
\text { used for curing ovarian and } \\
\text { breast cancer. }\end{array}$ \\
\hline $\begin{array}{l}\text { Urtica dioica L. [Urticaceae], } \\
\text { HT/SK/HAU/1589/2017 }\end{array}$ & Shouzhe (M) & Herb & Leaf & $\begin{array}{l}\text { The leaves are cooked and } \\
\text { consumed as vegetable. }\end{array}$ \\
\hline $\begin{array}{l}\text { Vaccinium glaucoalbum Hook.f. } \\
\text { ex C.B Clarke [Ericaceae]; } \\
\text { HT/SK/HAU/1592/2017 }\end{array}$ & $\begin{array}{l}\text { Shakshima } \\
(\mathrm{M})\end{array}$ & Shrub & Fruit & $\begin{array}{l}\text { Fruit are eaten to prevent } \\
\text { diarrhea, fever and throat } \\
\text { inflammation. Fruits are } \\
\text { sweet and consumable }\end{array}$ \\
\hline $\begin{array}{l}\text { Vaccinium retusum } \text { (Griff.) } \\
\text { Hook.f. ex C.B Clarke [Ericaceae]; } \\
\text { HT/SK/HAU/1591/2017 }\end{array}$ & $\begin{array}{l}\text { Seu Kyum } \\
\text { (M) }\end{array}$ & Shrub & Fruit & $\begin{array}{l}\text { Fruit is sweet and edible and } \\
\text { used as substitute for } \\
\text { Vaccinium glaucoalbum. }\end{array}$ \\
\hline $\begin{array}{l}\text { Zanthoxylum armatum } \text { DC. } \\
\text { [Rutaceae];HT/SK/HAU/1595/201 } \\
7\end{array}$ & $\begin{array}{l}\text { Yer, Zabrang } \\
\text { (M) } \\
\text { Honam }(\mathrm{N})\end{array}$ & Tree & $\begin{array}{l}\text { Leaf, } \\
\text { seed }\end{array}$ & $\begin{array}{l}\text { Fruits are taken as stimulant, } \\
\text { spice and condiment. The } \\
\text { powdered fruit is also taken } \\
\text { to cure cough and viral fever. }\end{array}$ \\
\hline $\begin{array}{l}\text { Zanthoxylum rhetsa DC. } \\
\text { [Rutaceae]; } \\
\text { HT/SK/HAU/1593/2018 }\end{array}$ & $\begin{array}{l}\text { Mechme }(M) \\
\text { Honyor }(N)\end{array}$ & Tree & Leaf & $\begin{array}{l}\text { The leaves consumed to treat } \\
\text { diarrhea and also consumed } \\
\text { as spice and condiment by } \\
\text { boiling with other vegetable } \\
\text { items. }\end{array}$ \\
\hline
\end{tabular}

\section{CONCLUSION}

From the present ethnobotanical investigation, it is concluded that Monpa and Nyishi community of West Kameng and Kamle district of Arunachal Pradesh is rich in traditional knowledge related to effective utilization of significant food and medicinal plants of their traditional biocultural landscape. Bonpo, the traditional healers of the Bon medical tradition of Monpa community, and Nyub and Nwn Pon Nwn Bo of the Nyishi community of the Abotani descendant who follow Donyi-Polo healing traditions were found to be the main custodian of the traditional healing practices of the two community under investigation. The food and medicinal species reported to be popularly used by both the community have indicated the nutritional and medicinal potential as well as economic value and commercial viability of the species reported. These consensus significant species frequently harvested and used by both the communities, and popularly sold in the market by them for economic, medicinal and nutritional security of their traditional biocultural landscape may be promoted for effective conservation and sustainable utilization.

\section{Acknowledgements}

The authors are thankful to all the local informants and traditional knowledge holders of West Kameng and Kamle district of Arunachal Pradesh for sharing their valuable indigenous knowledge during our field surveys. The authors are deeply thankful to G.B. Pant National Institute of Himalayan Environment \& Sustainable Development (GBPNIHESD), Almora for funding support under IERP scheme to NIT-AP; Board of Research in Nuclear Science (BRNS), BARC (Trombay), Department of Atomic Energy, GoI for funding support to RGU; Department of Biotechnology, GoI for funding support under DBT Twining and NER program to RGU and NITAP; and SERB, Department of Science \& Technology, GoI for funding support to NIT-AP. The authors thankfully acknowledge the administrative and logistic support rendered by Director NITAP Yupia and Registrar of Rajiv Gandhi University, Rono Hills, Doimukh, Arunachal Pradesh. 


\section{LITERATURE CITED}

Anonymous, 2011. CENSUS report: Arunachal Pradesh. Ministry of Home Affairs, Government of India. Pp. 5 - 20.

Chowdhery, H.J; Giri, G.S; Pal, G.D; Pramanik, A \& Das, S.K. 2009. Materials for the flora of Arunachal Pradesh. Vol. III. Botanical Survey of India, Kolkata.

Dam, D.P. \& Hajra, P.K. 1997. Observation on ethnobotany of Monpas of Kameng districts, Arunachal Pradesh. In: S.K. Jain (ed.), Contribution to Indian Ethnobotany. Scientific Publisher, Jodhpur, India. Pp.153 - 160.

Deki, T; Sanjib, D; Jambey, T; Pallabi, K.H \& Tag, H. 2018. Rapid ethnobotanical appraisal on Bugun, Sartang and Monpa communities of West Kameng and Tawang Sectors of Arunachal Himalayan Region, India. Pleione 12(2): 283 - 297.

Dhar, B. 2005. Arunachal Pradesh: The Monpas of Tawang in Transition. Geophil Publishing House, Guwahati, India.

Gajural, PR; Rethy, P \& Singh, B. 2003. Preliminary studies on wild edible plants resources of Dihang-Debang Biosphere Reserve. Abstract and Souvenir of $13^{\text {th }}$ Annual Conference of IAAT and International Symposium on Plant taxonomy: Advance\& Relevence, held at Department of Botany, TM Bhagalpur University, Bhagalpur, Bihar, $14-15$ November 2003, p.79.

Giri, G.S.; Pramanik, A. \& Chowdhery, H.J. 2008. Materials for the Flora of Arunachal Pradesh. Vol. II. Botanical Survey of India, Kolkata.

Hajra, P.K.; Verma, D.M. \& Giri, G.S. 1996. Materials for the Flora of Arunachal Pradesh. Vol. I. Botanical Survey of India, Calcutta.

Hooker, J.D. 1872 - 1897. The Flora of British India, Vols. 1 - 7. L. Reeve \& Co Ltd, Ashford, Kent. London.

Jain, S.K. \& Rao, R.R. 1977. A Handbook of Field and Herbarium Methods. Today \& Tomorrow's Printers and Publishers, New Delhi.

Jeri, L; Tag, H; Tsering, J; Kalita, P; Mingki, T \& Das, AK. 2011. Ethnobotanical investigation of edible and medicinal plants in Pakke wildlife sanctuary of East Kameng district in Arunachal Pradesh, India. Pleione 5(1): 83 - 90.

Kanjilal, U.N; Das, A.; Kanjilal, P.C.; Purkaystha, C.; De, R.N. \& Bor, N.L. $1934-1940$. Flora of Assam (Vols. I - V). Govt of Assam Press, Shillong..

Kaul, K.N. \& Haridasan, K. 1987. Forest types of Arunachal Pradesh: A preliminary study. J. Econ. Tax. Bot. 9(2): 379.

Martin, G.J. 2008. Ethnobotany: A Methods Manual, People and Plants Conservation Series. Earthscan, UK and USA. Pp. $10-160$.

Momang, T; Das, A.P \& Tag, H. 2018. A new species of Panax L. (Araliaceae) from Arunachal Pradesh, India. Pleione 12(2): 315 - 321.

Namsa, ND; Mandal, M; Tangjang, S \& Mandal, SC. 2011. Ethnobotany of the Monpa ethnic group at Arunachal Pradesh, India. J. Ethnobio. Etnomed. 7: 31.

Norbu, T. 2008. The Monpas of Tawang: Arunachal Pradesh. Director of Research, Department of Cultural Affairs, Arunachal Pradesh. Pp. $40-180$.

Omem, R; Rajiv, M \& Tag, H. 2016. Ethnobotany of the Galo community of Arunachal Pradesh, India. Pleione 10(2): 248 - 261. 
Pal, G.D. 1993. Flora of Lower Subansiri District, Arunachal Pradesh, India. Ph.D thesis, University of Calcutta, Calcutta. (Unpublished).

Pallabi, K; Tag, H.; Sarma, H.N. \& Das, AK. 2014. Evaluation of Nutritional Potential of Five Unexplored Wild Edible Food Plants from Eastern Himalayan Biodiversity Hotspot Region (India). Intn. J. Biol. Life Sci. Engin. 8(3): 1 - 4.

Rinyo, R; Momang, T; Pallabi, K.H \& Tag, H. 2018. Ethnobotanical resources and traditional skills prevalent among the Tagin community of Arunachal Pradesh, India. Pleione 12(2): $265-274$.

Singh, R.K.; Singh, A\& Sureja, A.K. 2007. Traditional foods of Monpa tribe of West Kameng, Arunachal Pradesh. Indian J. Trad. Knowl. 6(1): 25 - 36

Tag, H \& Das, A.K. 2007. Significant plant used by the Nyishi tribe of Arunachal Pradesh, Northeast India. In: A.P. Das \& A.K. Pandey (eds.), Advances in Ethnobotany. Bishen Singh and Mahindra Pal Singh. Dehradun. Pp. 43 - 50.

Tag, H \& Das, AK. 2003. Significant plants among the Nyishi tribe of Arunachal Pradesh (North East India), an ethnobotanical view. Abstract \& Souvenir of $13^{\text {th }}$ Annual Conference of IAAT and International Symposium on plant taxonomy: Advances \& Relevance held at Department of Botany, TM Bhagalpur University (Bhagalpur) Bihar, 14 - 15 November 2003, p.84.

Tag, H \& Das, A.K. 2004. Ethnobotanical notes on Hill Miri tribe of Arunachal Pradesh, India, Indian J. Trad. Knowl. 3(1): $80-85$.

Tag, H; Das, A.K. \& Pallabi, K. 2005. Plants used by Hill Miri tribe of Arunachal Pradesh in ethnofisheries. Indian J. Trad. Knowl. 4(1): 57 - 64.

Tag, H. 2007. A systematic study of plants of ethnomedicinal importance used by the Khamti Tribe of Arunachal Pradesh. PhD thesis, Rajiv Gandhi University, Itanagar. (Unpublished). Pp. $15-45$.

Tag, H. 2017. Heritage of the Kamle District, Arunachal Pradesh. A concept guide for district vision document 2030. Published by Department of Botany, Rajiv Gandhi University, Rono Hills, Doimukh, Arunachal Pradesh. Pp. 4 - 16.

Tag, H.; Murtem, G.; Das, A.K. \& Singh, R.K. 2008. Diversity distribution of ethnobotanical plants used by Adi tribe of East Siang district of Arunachal Pradesh, India. Pleione 2(1): $123-136$.

Tsering J; Gogoi B.J; Hui, P.K; Tam, N \& Tag, H. 2017. Ethnobotanical appraisal on wild edible plants used by the Monpa community of Arunachal Pradesh. Indian J. Trad. Knowl. 16 (4): $626-637$.

Tsering, J \& Tag, H. 2015. High altitude ethnomedicinal plants of Western Arunachal Himalayan Landscape. Pleione 9 (1): 18 - 25.

www.theplantlist.org 